\title{
C-reactive protein genetic variant is associated with diabetic retinopathy in Chinese patients with type 2 diabetes
}

Danfeng Peng ${ }^{\dagger}$, Jie Wang ${ }^{\dagger}$, Rong Zhang, Shanshan Tang, Feng Jiang, Miao Chen, Jing Yan, Xue Sun, Tao Wang, Shiyun Wang, Yuqian Bao, Cheng Hu* and Weiping Jia*

\begin{abstract}
Background: Diabetic retinopathy (DR) is an important microvascular complication of diabetes with a high concordance rate in patients with diabetes. Inflammation is supposed to participate in the development of DR. This study aimed to investigate whether genetic variants of CRP are associated with DR.

Methods: A total of 1,018 patients with type 2 diabetes were recruited in this study. Of these patients, 618 were diagnosed with DR, 400 were patients with diabetes for over 10 years but without DR, considered as cases and controls for DR, respectively. Four tagging SNPs (rs2808629, rs3093077, rs1130864 and rs2808634) within CRP region were genotyped for all the participants. Fundus photography was performed for diagnosis and classification for DR. Results: rs2808629 was significantly associated with increased susceptibility to DR (odds ratio 1.296, 95\% Cl 1.076-1.561, $P=0.006$, empirical $P=0.029$, for $\mathrm{G}$ allele). This association remained significant after adjustment for confounding factors (odds ratio 1.261, 95\% Cl 1.022-1.555, $P=0.030$ ).
\end{abstract}

Conclusions: In this study, we found CRP rs2808629 was associated with DR in the Chinese patients with type 2 diabetes.

Keywords: C-reactive protein, Diabetic retinopathy, Single nucleotide polymorphism, Inflammation, Type 2 diabetes

\section{Background}

Diabetes mellitus, especially type 2 diabetes mellitus (T2DM), has become a global epidemic. With the rapid rising incidence of T2DM, diabetic complications will certainly pose a major public health concern in the coming decades. Diabetic retinopathy (DR) is a major microvascular complication of diabetes and ranks as the leading cause of blindness among working-aged adults around the world [1]. Epidemiological studies have shown that the incidence of DR parallels with diabetes duration and intensive glycaemic control can delay its development [2]. However it is noteworthy that some patients with good glycaemic control may still develop DR whereas some are spared from DR despite poor glycaemic control. Although the mechanisms underlie this observation remains largely

\footnotetext{
* Correspondence: alfredhc@sjtu.edu.cn; wpjia@sjtu.edu.cn

${ }^{\dagger}$ Equal contributors

Shanghai Diabetes Institute, Shanghai Key Laboratory of Diabetes Mellitus, Shanghai Clinical Center for Diabetes, Shanghai Jiao Tong University Affiliated Sixth People's Hospital, 600 Yishan Road, Shanghai 200233, China
}

unknown, inherited susceptibility may modulate the risk of DR because retinopathy aggregates in families. Siblings of patients with T2DM who have DR showed a significant higher risk of DR compared to siblings of patients with T2DM who have no DR [3,4]. Significant familial influence on the severity of DR was also observed $[5,6]$ and the risk of DR varies among different ethnic groups [7-9]. To data, although no locus for DR from genome-wide association study (GWAS) has reached conventional significance criteria, but a significant number of genes and genetic variants have been proposed for DR or proliferative DR through candidate gene approach [10,11]. Several pathways and processes, including the renin-angiotensin system, vascular endothelial dysfunction, tissue matrix remodeling, and angiogenesis, have been strongly implicated in the pathogenesis of DR, and multiple genes involved in these pathways have been identified for DR (e.g., AKR1B1, VEGFA, $A C E$, and $A G E R$ ).

C-reactive protein (CRP), a very sensitive marker of inflammation produced by the liver cells in response to 
various stimuli, is involved in endothelial dysfunction and angiogenesis $[12,13]$ which have been proposed to play an important role in the pathogenesis of DR $[14,15]$. It is now well accepted that CRP is a strong predictor of future cardiovascular events $[16,17]$. However, less is known about its relationship with microvascular complications of diabetes. In this regard, some, though not all, studies (especially prospective studies) have reported that circulating CRP is associated with diabetic nephropathy $(\mathrm{DN})[18,19]$ and $\mathrm{DR}[15,20]$ in the last decade, raising the possibility that the increase of CRP may be an early event or even one of driving forces in the development of microvascular complications of diabetes. Therefore, it is plausible to hypothesize that genetic variants of $C R P$ may have impact on the risk of these complications. In the current study, we investigated the association between $C R P$ variants and DR in a Chinese population.

\section{Methods}

\section{Participants}

This study involved 1,018 patients with T2DM recruited from the Shanghai Diabetes Institute Inpatient Database of Shanghai Jiao Tong University Affiliated Sixth People's Hospital. All participants were unrelated patients with T2DM meeting the $1999 \mathrm{WHO}$ criteria (fasting plasma glucose $\geq 7.0 \mathrm{mmol} / \mathrm{l}$ and/or $2 \mathrm{~h}$ plasma glucose $\geq$ $11.1 \mathrm{mmol} / \mathrm{l})$. Type 1 diabetes and mitochondrial diabetes were excluded by clinical, immunological (individuals with GAD and/or protein tyrosine phosphatase IA-2 antibodies were excluded) and genetic methods (mitochondrial tRNA $^{\text {Leu(UUR) }}$ A3243G mutation carriers were excluded). Of these patients, 618 were diagnosed with DR, 400 were patients without DR, considered as cases and controls for DR, respectively. For controls selection, patients with diabetes for over 10 years were chosen deliberately. This study was approved by the institutional review board of Shanghai Jiao Tong University Affiliated Sixth People's Hospital, with written informed consent obtained from each participant.

\section{Clinical measurement}

Each participant completed a standard questionnaire for detailed information as described previously [21]. Fundus photography was performed according to a standardized protocol at the Department of Ophthalmology, Shanghai Jiao Tong University Affiliated Sixth People's Hospital. Both eyes of each patient were photographed with a 45degree 6.3-megapixel digital nonmydriatic camera (Canon CR6-45NM, Lake Success, NY). A five-stage disease severity classification for DR was applied according to the International Classification of Diabetic Retinopathy [22]: no apparent retinopathy (no abnormalities), mild nonproliferative diabetic retinopathy (NPDR) (microaneurysms only), moderate NPDR (more than just microaneurysms but less than severe NPDR), severe NPDR (more than 20 intraretinal hemorrhages in each of 4 quadrants and/or definite venous beading in 2 quadrants and/or prominent intraretinal microvascular abnormalities in 1quadrant and no signs of proliferative retinopathy), or proliferative diabetic retinopathy (PDR) (neovascularization and/or vitreous hemorrhage and/or preretinal hemorrhage). DR grade was evaluated for both eyes, and higher grade was recorded for each person. Of the 618 patients with DR in this study, there were 395 with mild NPDR, 103 with moderate NPDR, 84 with severe NPDR, and 36 with PDR. Body mass index (BMI) was calculated as weight in kilograms divided by height in meters squared. Glycaemic control was evaluated by measuring glycated haemoglobin (HbA1c) levels. Data of blood pressures and lipid profiles were also collected for each participant. Hypertension was defined as systolic blood pressure $\geq 140 \mathrm{mmHg}$ and/or diastolic blood pressure $\geq 90 \mathrm{mmHg}$.

\section{Single nucleotide polymorphisms (SNPs) selection, genotyping and quality control}

In this study, we selected four tagging SNPs (rs2808629, rs3093077, rs1130864 and rs2808634) that spanned $11 \mathrm{~kb}$ in the upstream and $6 \mathrm{~kb}$ in the downstream region of CRP, according to HapMap phase III (release 28) Han Chinese database with a threshold of $r^{2} \geq 0.8$. We could tag 95\% SNPs (21 out of 22 SNPs) with a minor allele frequency $(\mathrm{MAF})>0.01$ within $C R P$ region. All genotyping was done using the primer extension of multiplex products with detecting by matrix-assisted laser desorption ionization-time of flight mass spectroscopy using a MassARRAY Compact Analyzer (Sequenom, San Diego, CA, USA). The genotyping data underwent a series of quality control checks and cleaned data were used in further statistical analysis. The call rates for rs2808629, rs3093077, rs1130864 and rs2808634 were 97.0\%, 95.9\%, $98.3 \%$ and $96.9 \%$, respectively. The concordance rates based on 100 duplicates were over $99 \%$ for all these SNPs. Thirty-seven individuals were excluded from the sample call rate checks. The Hardy-Weinberg equilibrium test was performed before the association analysis, and all the four SNPs were in accordance with HardyWeinberg equilibrium $(P=0.68$ for $\mathrm{rs} 2808629, P=0.74$ for rs3093077, $P=0.34$ for rs1130864 and $P=0.47$ for rs2808634, respectively).

\section{Statistical analysis}

The allelic frequencies between the patients with or without DR were compared by $\chi^{2}$ test, and odds ratios with 95\% confidence intervals (CIs) were presented. Genotype distributions between patients with or without DR were compared using multiple logistic regressions under an additive model with adjustment for confounding factors. 
The effects of SNPs on the levels of retinopathy severity were analyzed by trend analysis. All these analyses were performed using SAS 9.3 (SAS institute, Cary, NC, USA) unless specified otherwise. A two-tailed $P$ value $<0.05$ was considered statistically significant.

On the basis of the previously reported effect size of genetic loci for DR ( 1.40) [10], our samples had $>90 \%$ power to detect an effect SNP with MAF of 0.3 and > $80 \%$ power to detect an effect SNP with MAF of 0.2 at a level of significance of 0.05 .

\section{Results}

The clinical characteristics of the subjects passed genotype quality control were shown in Table 1. Compared with patients without DR, patients with DR were diagnosed with diabetes at earlier age and had higher HbA1c levels and higher prevalence of hypertension and diabetic nephropathy. Besides, as patients without DR with diabetes for over 10 years were selected in our study, they were older and had longer duration of diabetes compared with patients with DR.

We firstly analyzed the association between these SNPs and the risk of DR. As shown in Table 2, rs2808629 was nominally associated with increased susceptibility to DR (odds ratio 1.296, 95\% CI 1.076-1.561, $P=0.006$, for G allele). This association remained significant after adjusting for confounding factors, including HbA1c levels, duration of diabetes, systolic and diastolic blood pressure, BMI and sex (odds ratio 1.261, 95\% CI 1.022-1.555, $P=0.030$ ), as well as adjusting for multiple comparisons (empirical $P=$ 0.029). The other SNPs did not show any association with DR. Further, we tried to examine the effect of rs 2808629 on the disease severity of DR. Of the 593 DR patients, there were 379 patients with mild NPDR, 98 with moderate NPDR, 80 with severe NPDR and 36 with PDR. However, no significant association of rs2808629 with DR severity was observed ( $P=0.387$ for trend analysis). The distributions of these four SNPs among patients with different levels of DR were shown in Table 3. In addition, rs2808629 was genotyped among 438 subjects with normal glucose regulation. The distribution of this SNP was similar to those reported in other studies of Asian populations in the HapMap database (G allele frequency 0.453 vs $0.419 / 0.297 / 0.537$ ), indicating that there was no technical error in this study.

\section{Discussion}

In the present study, we investigated the association of $C R P$ variants with DR in Chinese patients with T2DM. It's the first time to our knowledge to investigate the association between CRP variants with DR. Our results revealed that rs2808629 was significantly associated with the risk of DR in Chinese patients with T2DM. This association remained significant after adjusting for multiple comparisons. Moreover, the correlation of rs2808629 with DR stayed significant after adjusting for confounding factors, including duration of diabetes, HbA1c, blood pressure, BMI and sex, implying that this SNP is an independent genetic factor for susceptibility to DR. It has been reported in several studies that $C R P$ genetic variants were associated with serum CRP levels [23-28]. rs2808629 was identified to be associated with serum CRP levels in a previous genome-wide association study [23]. Therefore, it is plausible that the effect of rs 2808629 on susceptibility to DR is because of its influence on serum CRP levels. However, further studies are needed for confirmation.

As an acute phase reactant, CRP production increases in response to a variety of systemic events such as infection, trauma, or autoimmune inflammatory diseases. Among other systemic inflammatory mediators, CRP has been widely accepted as a potent risk indicator, independently predicting future cardiovascular events in the last decades

Table 1 Clinical characteristics of the study patients

\begin{tabular}{|c|c|c|c|}
\hline Characteristic & $\begin{array}{l}\text { Diabetic retinopathy } \\
(n=593)\end{array}$ & $\begin{array}{l}\text { Patients without retinopathy } \\
(\mathrm{n}=388)\end{array}$ & $P$ value \\
\hline Male/female (n) & $285 / 308$ & $154 / 234$ & 0.010 \\
\hline Age (years) & $62.48 \pm 10.79$ & $67.37 \pm 9.62$ & $<0.0001$ \\
\hline $\mathrm{BMI}\left(\mathrm{kg} / \mathrm{m}^{2}\right)$ & $24.12 \pm 3.65$ & $24.02 \pm 3.36$ & 0.861 \\
\hline Age at diagnosis of diabetes (years) & $51.70 \pm 10.60$ & $53.39 \pm 9.87$ & 0.014 \\
\hline Duration of diabetes (years) & $10.00(5.00,15.00)$ & $12.00(10.00,16.00)$ & $<0.0001$ \\
\hline $\mathrm{HbA1c}(\%)$ & $9.16 \pm 2.17$ & $8.70 \pm 2.11$ & 0.0003 \\
\hline Systolic blood pressure (mmHg) & $138.66 \pm 18.90$ & $135.98 \pm 17.83$ & 0.014 \\
\hline Diastolic blood pressure $(\mathrm{mmHg})$ & $81.39 \pm 9.55$ & $79.34 \pm 9.45$ & 0.001 \\
\hline Subjects with hypertension [n (\%)] & $335(56.5 \%)$ & $186(47.9 \%)$ & 0.009 \\
\hline Subjects with nephropathy [n (\%)] & $232(39.1 \%)$ & 113(29.1\%) & 0.001 \\
\hline
\end{tabular}

Data are $n$, mean \pm SD or median (interquartile range). BMI, body mass index.

25 patients with DR and 12 patients without DR were excluded due to sample call rate check. 
Table 2 Associations of CRP SNPs with diabetic retinopathy

\begin{tabular}{|c|c|c|c|c|c|c|c|c|c|c|c|c|}
\hline \multirow[t]{2}{*}{ SNP } & \multirow[t]{2}{*}{$\begin{array}{l}\text { Chr: position } \\
\text { (Build 38) }\end{array}$} & \multirow[t]{2}{*}{$\begin{array}{l}\text { Reference } \\
\text { position* }\end{array}$} & \multirow[t]{2}{*}{$\begin{array}{l}\text { Major/minor } \\
\text { allele }\end{array}$} & \multirow[t]{2}{*}{$\begin{array}{l}\text { Risk } \\
\text { allele }\end{array}$} & \multicolumn{2}{|l|}{$\begin{array}{l}\text { Cases } \\
(n=593)\end{array}$} & \multicolumn{2}{|l|}{$\begin{array}{l}\text { Controls } \\
(n=388)\end{array}$} & \multirow[t]{2}{*}{ OR $(95 \%$ Cl) } & \multirow[t]{2}{*}{$\begin{array}{l}P \text { value } \\
\text { (empirical } \\
P \text { value) }\end{array}$} & \multirow[t]{2}{*}{$\begin{array}{l}\text { OR } \\
(95 \% \mathrm{Cl})^{\S}\end{array}$} & \multirow[t]{2}{*}{$\begin{array}{l}P \\
\text { value }^{\S}\end{array}$} \\
\hline & & & & & $\begin{array}{l}\text { Minor allele } \\
\text { frequencies }\end{array}$ & $\begin{array}{l}\text { Genotype } \\
\text { count } 11 / 12 / 22^{\#}\end{array}$ & $\begin{array}{l}\text { Minor allele } \\
\text { frequencies }\end{array}$ & $\begin{array}{l}\text { Genotype count } \\
11 / 12 / 22^{\#}\end{array}$ & & & & \\
\hline rs2808629 & 1:159707006 & +5283 & $A / G$ & G & 0.452 & 171/297/115 & 0.389 & $141 / 180 / 57$ & $1.296(1.076,1.561)$ & $0.006(0.029)$ & $1.261(1.022,1.555)$ & 0.030 \\
\hline rs3093077 & 1:159709846 & +2443 & $T / G$ & G & 0.183 & $390 / 179 / 18$ & 0.163 & 271/106/10 & $1.153(0.906,1.468)$ & $0.248(0.612)$ & $1.194(0.906,1.574)$ & 0.209 \\
\hline rs1130864 & 1:159713301 & $3^{\prime}$ UTR & $C / T$ & T & 0.058 & $520 / 62 / 3$ & 0.045 & $352 / 33 / 1$ & $1.299(0.855,1.974)$ & $0.219(0.667)$ & $1.250(0.794,1.968)$ & 0.335 \\
\hline rs2808634 & 1:159722783 & -8194 & $\mathrm{C} / \mathrm{T}$ & T & 0.160 & $420 / 155 / 17$ & 0.151 & 281/97/10 & $1.070(0.833,1.375)$ & $0.597(0.968)$ & $1.056(0.804,1.386)$ & 0.697 \\
\hline
\end{tabular}

$P$ values $<0.05$ are shown in bold.

The additive model was used in the association analysis between genotype and DR

*position of SNP with reference to CRP.

\#11, major allele homozygotes; 12 , heterozygotes; 2 2, minor allele homozygotes.

sadjusted for duration of diabetes, HbA1c, systolic blood pressure, diastolic blood pressure, body mass index and sex.

Empirical $P$ values are based on 10,000 permutations.

The OR with $95 \% \mathrm{Cl}$ shown is for the minor allele. 
Table 3 CRP SNPs distributions among patients with different severities of DR

\begin{tabular}{|c|c|c|c|c|c|c|c|c|}
\hline \multirow[t]{2}{*}{ SNP } & \multicolumn{2}{|l|}{$\begin{array}{l}\text { Mild NPDR } \\
(\mathrm{n}=379)\end{array}$} & \multicolumn{2}{|c|}{$\begin{array}{l}\text { Moderate NPDR } \\
(\mathrm{n}=98)\end{array}$} & \multicolumn{2}{|l|}{$\begin{array}{l}\text { Severe NPDR } \\
(n=80)\end{array}$} & \multicolumn{2}{|l|}{$\begin{array}{l}\text { PDR } \\
(n=36)\end{array}$} \\
\hline & $\begin{array}{l}\text { Minor allele } \\
\text { frequencies }\end{array}$ & $\begin{array}{l}\text { Genotype count } \\
11 / 12 / 22^{\#}\end{array}$ & $\begin{array}{l}\text { Minor allele } \\
\text { frequencies }\end{array}$ & $\begin{array}{l}\text { Genotype count } \\
11 / 12 / 22^{\#}\end{array}$ & $\begin{array}{l}\text { Minor allele } \\
\text { frequencies }\end{array}$ & $\begin{array}{l}\text { Genotype count } \\
11 / 12 / 22^{\#}\end{array}$ & $\begin{array}{l}\text { Minor allele } \\
\text { frequencies }\end{array}$ & $\begin{array}{l}\text { Genotype count } \\
11 / 12 / 22^{\#}\end{array}$ \\
\hline rs2808629 & 0.465 & $110 / 180 / 84$ & 0.463 & $25 / 52 / 18$ & 0.405 & $25 / 44 / 10$ & 0.386 & $11 / 21 / 3$ \\
\hline rs3093077 & 0.196 & $242 / 122 / 13$ & 0.168 & $67 / 24 / 4$ & 0.163 & $55 / 24 / 1$ & 0.129 & $26 / 9 / 0$ \\
\hline rs1130864 & 0.053 & $339 / 34 / 3$ & 0.072 & $83 / 14 / 0$ & 0.058 & $69 / 9 / 0$ & 0.074 & $29 / 5 / 0$ \\
\hline rs2808634 & 0.166 & $263 / 106 / 10$ & 0.168 & $69 / 25 / 4$ & 0.127 & $61 / 16 / 2$ & 0.139 & $27 / 8 / 1$ \\
\hline
\end{tabular}

\#11, major allele homozygotes; 12 , heterozygotes; 22, minor allele homozygotes.

[29-31]. On the other hand, given the increasingly recognized link between chronic inflammation and microvascular complications [15,32], the relationship between CRP and DR has been investigated in some studies. However, results from limited studies on possible association of CRP with DR are inconsistent. In the Hoorn study [15], a large population-based cohort study of 625 adults, higher CRP was associated with the prevalence of any DR. Another prospective study of inflammatory biomarkers and risk of DR in the Diabetes Control and Complications Trial also indicated that after adjusting for known risk factors, increasing quintiles of baseline high-sensitivity CRP (hsCRP) level may be associated with higher risks of incident clinically significant macular edema and the development of macular hard exudates [33]. However, report from the Wisconsin Epidemiologic Study of Diabetic Retinopathy (WESDR) [34], a longitudinal population based study of persons with type 1 diabetes, did not find any association between CRP and DR. Similar results were reported by the Multi-ethnic Study of Atherosclerosis (MESA) [35]. Besides, Lim et al. [36] reported that patients with higher levels of CRP were less likely to have DR in the Singapore Malay Eye Study (SiMES), a cross-sectional study on 718 persons with diabetes. Nevertheless, emerging evidence supports CRP as an active participant instead of a mere bystander in the pathogenesis of DR. CRP could inhibit endothelium-dependent nitric oxide-mediated dilation in retinal arterioles, thus potentially facilitating the development of retinal vascular diseases [37]. Besides, CRP could stimulate leucocyte-endothelium interactions [38], decrease endothelial nitric oxide [39], and impair the number and function of endothelial progenitor cells [40], thereby promoting endothelial dysfunction, which is another important mediator in the development of diabetic microvascular complications [15]. Taken together, these findings imply that genetic variants of $C R P$ may exert significant effects on DR. And our study found a common variant of CRP, rs2808629, was significantly associated with DR in the Chinese patients with T2DM.

Some limitations should be noted in our study. Firstly, although the association of rs2808629 with DR remained significant after adjusting for multiple comparisons (empirical
$P=0.029$ ), we still cannot fully exclude the possibility that the association detected was a false positive. But considering the power of our study samples and the effect of this SNP, the possibility of a false positive is limited. Secondly, rs2808629 locates in the downstream of CRP, and we suppose that it may participate in the susceptibility to DR through its effects on regulating CRP expression or it may be just a genetic marker in linkage disequilibrium with the causal variant(s). However, further studies are needed to reveal the underlying mechanism. Thirdly, although we found association of $C R P$ variant with DR in Chinese patients with T2DM, whether this effect is restricted to T2DM is still unknown and needs to be investigated in studies among patients with type 1 diabetes and other ethnic groups.

\section{Conclusions}

In summary, we found that CRP rs2808629 was associated with DR in Chinese patients with T2DM. This study discover the association of CRP variant with DR for the first time, although the mechanism underlying the genotype-phenotype association is unknown, it provides a hypothesis for future researches. Further studies are needed to replicate this finding in other populations and translate the common variant association signal into biological mechanisms of disease causation.

\section{Abbreviations \\ T2DM: Type 2 diabetes mellitus; DR: Diabetic retinopathy; DN: Diabetic nephropathy; GWAS: Genome-wide association study; CRP: C-reactive protein; NPDR: Nonproliferative diabetic retinopathy; PDR: Proliferative diabetic retinopathy; HbA1c: Glycated haemoglobin; SNP: Single nucleotide polymorphism; BMl: Body mass index; hsCRP: High-sensitivity CRP.}

Competing interests

The authors declare that they have no competing interests.

\section{Authors' contributions}

DP and JW carried out the majority of the analyses and drafted the manuscript. RZ, ST and FJ participated in the design of the study. MC, JY, XS, TW and SW participated in the data analysis. YB provided helpful comments on study design and data analysis. $\mathrm{CH}$ and WJ conceived the study, and participated in its design and helped to draft the manuscript. All authors read and approved the final manuscript. 


\section{Acknowledgments}

This work was supported by grant from the National 973 Program (2011CB504001), the National 863 program (2012AA02A509), NSFC (81200582 and 81322010), Excellent Young Medical Expert of Shanghai (XYQ2011041), Shanghai Talent Development Grant (2012041), National Young Top Talent Supporting Program, the Drug Innovation Program of the National Science and Technology Project (2011ZX09307-001-02) and grant from Shanghai Health and Family Planning Commission (2013ZYJB1001). The authors appreciate all the participants of this research and gratefully acknowledge the skillful technical support of all nursing and medical staff at Shanghai Clinical Center for Diabetes.

\section{Received: 4 March 2014 Accepted: 18 February 2015} Published online: 02 March 2015

\section{References}

1. Klein BE. Overview of epidemiologic studies of diabetic retinopathy. Ophthalmic Epidemiol. 2007;14(4):179-83.

2. Stratton IM, Adler Al, Neil HA, Matthews DR, Manley SE, Cull CA, et al. Association of glycaemia with macrovascular and microvascular complications of type 2 diabetes (UKPDS 35): prospective observational study. BMJ. 2000;321(7258):405-12.

3. Rema M, Saravanan G, Deepa R, Mohan V. Familial clustering of diabetic retinopathy in South Indian Type 2 diabetic patients. Diabet Med. 2002;19(11):910-6.

4. Murea M, Ma L, Freedman BI. Genetic and environmental factors associated with type 2 diabetes and diabetic vascular complications. Rev Diabet Stud. 2012;9(1):6-22

5. The Diabetes Control and Complications Trial/Epidemiology of Diabetes Interventions and Complications Research Group. Retinopathy and nephropathy in patients with type 1 diabetes four years after a trial of intensive therapy. The New England journal of medicine. 2000;342(6):381-9.

6. Arar NH, Freedman Bl, Adler SG, lyengar SK, Chew EY, Davis MD, et al. Heritability of the severity of diabetic retinopathy: the FIND-Eye study. Invest Ophthalmol Vis Sci. 2008:49(9):3839-45.

7. Tudor SM, Hamman RF, Baron A, Johnson DW, Shetterly SM. Incidence and progression of diabetic retinopathy in Hispanics and non-Hispanic whites with type 2 diabetes. San Luis Valley Diabetes Study, Colorado. Diabetes Care. 1998:21(1):53-61.

8. Hallman DM, Huber Jr JC, Gonzalez VH, Klein BE, Klein R, Hanis CL. Familial aggregation of severity of diabetic retinopathy in Mexican Americans from Starr County, Texas. Diabetes Care. 2005;28(5):1163-8.

9. Velho G, Vaxillaire M, Boccio V, Charpentier G, Froguel P. Diabetes complications in NIDDM kindreds linked to the MODY3 locus on chromosome 12q. Diabetes Care. 1996;19(9):915-9.

10. Ng DP. Human genetics of diabetic retinopathy: current perspectives. J Ophthalmol. 2010;2010:172593.

11. Petrovic D. Candidate genes for proliferative diabetic retinopathy. Biomed Res Int. 2013;2013:540416.

12. Verma S, Wang CH, Li SH, Dumont AS, Fedak PW, Badiwala MV, et al. A selffulfilling prophecy: C-reactive protein attenuates nitric oxide production and inhibits angiogenesis. Circulation. 2002;106(8):913-9.

13. Verma S, Li SH, Badiwala MV, Weisel RD, Fedak PW, Li RK, et al. Endothelin antagonism and interleukin-6 inhibition attenuate the proatherogenic effects of C-reactive protein. Circulation. 2002;105(16):1890-6.

14. Crawford TN, Alfaro 3rd DV, Kerrison JB, Jablon EP. Diabetic retinopathy and angiogenesis. Curr Diabetes Rev. 2009;5(1):8-13.

15. van Hecke MV, Dekker JM, Nijpels G, Moll AC, Heine RJ, Bouter LM, et al. Inflammation and endothelial dysfunction are associated with retinopathy: the Hoorn Study. Diabetologia. 2005;48(7):1300-6.

16. Koenig W, Sund M, Frohlich M, Fischer HG, Lowel H, Doring A, et al. CReactive protein, a sensitive marker of inflammation, predicts future risk of coronary heart disease in initially healthy middle-aged men: results from the MONICA (Monitoring Trends and Determinants in Cardiovascular Disease) Augsburg Cohort Study, 1984 to 1992. Circulation. 1999;99(2):237-42.

17. Pradhan AD, Manson JE, Rifai N, Buring JE, Ridker PM. C-reactive protein, interleukin 6, and risk of developing type 2 diabetes mellitus. JAMA. 2001;286(3):327-34

18. Overgaard AJ, McGuire JN, Hovind P, Parving HH, Rossing P, Pociot F. Serum amyloid $A$ and $C$-reactive protein levels may predict microalbuminuria and macroalbuminuria in newly diagnosed type 1 diabetic patients. J Diabetes Complications. 2013;27(1):59-63.

19. Hansen TK, Forsblom C, Saraheimo M, Thorn L, Waden J, Hoyem P, et al. Association between mannose-binding lectin, high-sensitivity C-reactive protein and the progression of diabetic nephropathy in type 1 diabetes. Diabetologia. 2010;53(7):1517-24.

20. Nowak M, Wielkoszynski T, Marek B, Kos-Kudla B, Swietochowska E, Sieminska L, et al. Antioxidant potential, paraoxonase 1, ceruloplasmin activity and C-reactive protein concentration in diabetic retinopathy. Clin Exp Med. 2010;10(3):185-92.

21. Jia WP, Pang C, Chen L, Bao YQ, Lu JX, Lu HJ, et al. Epidemiological characteristics of diabetes mellitus and impaired glucose regulation in a Chinese adult population: the Shanghai Diabetes Studies, a cross-sectional 3-year follow-up study in Shanghai urban communities. Diabetologia. 2007:50(2):286-92

22. Wilkinson CP, Ferris 3rd FL, Klein RE, Lee PP, Agardh CD, Davis M, et al Proposed international clinical diabetic retinopathy and diabetic macular edema disease severity scales. Ophthalmology. 2003;110(9):1677-82.

23. Benjamin EJ, Dupuis J, Larson MG, Lunetta KL, Booth SL, Govindaraju DR, et al. Genome-wide association with select biomarker traits in the Framingham Heart Study. BMC Med Genet. 2007;8 Suppl 1:S11.

24. Schumacher W, Cockcroft J, Timpson NJ, McEniery CM, Gallacher J, Rumley A, et al. Association between C-reactive protein genotype, circulating levels, and aortic pulse wave velocity. Hypertension. 2009;53(2):150-7.

25. Lee CC, You NC, Song Y, Hsu YH, Manson J, Nathan L, et al. Relation of genetic variation in the gene coding for $\mathrm{C}$-reactive protein with its plasma protein concentrations: findings from the Women's Health Initiative Observational Cohort. Clin Chem. 2009:55(2):351-60.

26. Teng MS, Hsu LA, Wu S, Chang HH, Chou HH, Ko YL. Association between $\mathrm{C}$-reactive protein gene haplotypes and C-reactive protein levels in Taiwanese: interaction with obesity. Atherosclerosis. 2009;204(2):e64-9.

27. Komurcu-Bayrak E, Erginel-Unaltuna N, Onat A, Ozsait B, Eklund C, Hurme M, et al. Association of C-reactive protein (CRP) gene allelic variants with serum CRP levels and hypertension in Turkish adults. Atherosclerosis. 2009;206(2):474-9.

28. Kong H, Qian YS, Tang XF, Zhang J, Gao PJ, Zhang Y, et al. C-reactive protein (CRP) gene polymorphisms, CRP levels and risk of incident essential hypertension: findings from an observational cohort of Han Chinese. Hypertens Res. 2012;35(10):1019-23.

29. Haverkate F, Thompson SG, Pyke SD, Gallimore JR, Pepys MB. Production of C-reactive protein and risk of coronary events in stable and unstable angina. European Concerted Action on Thrombosis and Disabilities Angina Pectoris Study Group. Lancet. 1997:349(9050):462-6.

30. Liuzzo G, Biasucci LM, Gallimore JR, Grillo RL, Rebuzzi AG, Pepys MB, et al. The prognostic value of $C$-reactive protein and serum amyloid a protein in severe unstable angina. N Engl J Med. 1994;331(7):417-24

31. Ridker PM, Buring JE, Shih J, Matias M, Hennekens $\mathrm{CH}$. Prospective study of C-reactive protein and the risk of future cardiovascular events among apparently healthy women. Circulation. 1998:98(8):731-3.

32. Goldberg RB. Cytokine and cytokine-like inflammation markers, endothelial dysfunction, and imbalanced coagulation in development of diabetes and its complications. J Clin Endocrinol Metab. 2009;94(9):3171-82.

33. Muni RH, Kohly RP, Lee EQ, Manson JE, Semba RD, Schaumberg DA. Prospective study of inflammatory biomarkers and risk of diabetic retinopathy in the diabetes control and complications trial. JAMA Ophthalmol. 2013;131(4):514-21.

34. Klein BE, Knudtson MD, Tsai MY, Klein R. The relation of markers of inflammation and endothelial dysfunction to the prevalence and progression of diabetic retinopathy: Wisconsin epidemiologic study of diabetic retinopathy. Arch Ophthalmol. 2009:127(9):1175-82.

35. Nguyen TT, Alibrahim E, Islam FM, Klein R, Klein BE, Cotch MF, et al. Inflammatory, hemostatic, and other novel biomarkers for diabetic retinopathy: the multi-ethnic study of atherosclerosis. Diabetes Care. 2009:32(9):1704-9.

36. Lim LS, Tai ES, Mitchell P, Wang JJ, Tay WT, Lamoureux E, et al. C-reactive protein, body mass index, and diabetic retinopathy. Invest Ophthalmol Vis Sci. 2010;51(9):4458-63.

37. Nagaoka T, Kuo L, Ren Y, Yoshida A, Hein TW. C-reactive protein inhibits endothelium-dependent nitric oxide-mediated dilation of retinal arterioles via enhanced superoxide production. Invest Ophthalmol Vis Sci. 2008:49(5):2053-60. 
38. Devaraj S, Davis B, Simon SI, Jialal I. CRP promotes monocyte-endothelial cell adhesion via Fcgamma receptors in human aortic endothelial cells under static and shear flow conditions. Am J Physiol Heart Circ Physiol. 2006;291(3):H1170-6.

39. Venugopal SK, Devaraj S, Yuhanna I, Shaul P, Jialal I. Demonstration that C-reactive protein decreases eNOS expression and bioactivity in human aortic endothelial cells. Circulation. 2002;106(12):1439-41.

40. Kalka C, Masuda H, Takahashi T, Kalka-Moll WM, Silver M, Kearney M, et al. Transplantation of ex vivo expanded endothelial progenitor cells for therapeutic neovascularization. Proc Natl Acad Sci U S A. 2000;97(7):3422-7.

Submit your next manuscript to BioMed Central and take full advantage of:

- Convenient online submission

- Thorough peer review

- No space constraints or color figure charges

- Immediate publication on acceptance

- Inclusion in PubMed, CAS, Scopus and Google Scholar

- Research which is freely available for redistribution 